\title{
Conservation related insights into the behaviour of the olive ridley sea turtle Lepidochelys olivacea nesting in Oman
}

\author{
ALan F. Rees ${ }^{1, *}$, Ali Al-Kiyumi ${ }^{2}$, Annette C. Broderick ${ }^{1}$, Nancy Papathanasopoulou ${ }^{3}$, \\ Brendan J. Godley ${ }^{1}$
}

${ }^{1}$ Marine Turtle Research Group, Centre for Ecology and Conservation, University of Exeter, Cornwall Campus, TR10 9EZ, UK ${ }^{2}$ Ministry of Environment and Climate Affairs, PO Box 323, Muscat, Sultanate of Oman

${ }^{3}$ Biodiversity East, PO Box 214383, Dubai, United Arab Emirates

\begin{abstract}
We followed the movements of 9 adult female olive ridley turtles Lepidochelys olivacea after nesting on Masirah Island, Oman, using satellite tracking. Their post-breeding migrations ranged from 85 to $796 \mathrm{~km}$. Three individuals travelled north to foraging grounds in Pakistan, Iran and the United Arab Emirates. The other 6 turtles remained in Omani seas for extended periods (mean $\pm \mathrm{SD}=171.3 \pm 109.4 \mathrm{~d}$; range $=40$ to $310 \mathrm{~d}$ ). These locally resident turtles experienced biannual cooling of sea temperatures due to the effect of the west Arabian Sea upwelling which was not experienced by those that migrated to the north. Indications of disparity in turtle size between foraging locations are identified for the first time in this species. The majority of turtles (8) settled in coastal areas of water depth $<100 \mathrm{~m}$. Two locally resident turtles remained in very shallow water $(<40 \mathrm{~m}$ depth) where they were capable of extended dive durations ( $>100 \mathrm{~min})$ in water warmer than $21^{\circ} \mathrm{C}$, which is a feature unique to olive ridleys amongst sea turtles. They displayed a shift to shorter diving after breeding, indicating increased activity levels. The entire spatial footprint of olive ridley dispersal remained within a putative regional management unit (RMU) for this species in the western Indian Ocean, supporting its delineation. We reveal Oman's key role in conserving this demographic unit, with 6 turtles remaining within its national boundary. Our data add to the growing body of evidence that marine turtles show varied migration behaviours within populations, thus complicating their management.
\end{abstract}

KEY WORDS: Lepidochelys olivacea - Satellite tracking · Migration · Behavioural plasticity · Nesting $\cdot$ Indian Ocean

Resale or republication not permitted without written consent of the publisher

\section{INTRODUCTION}

In order to effectively manage migratory vertebrates, it is necessary to gain insights into their spatial ecology (e.g. Baker et al. 1990, Tuck et al. 2001, Wilcove \& Wikelski 2008). The recent advent of remote tracking technologies has greatly improved our ability to understand patterns of movement of marine vertebrates (Block et al. 2001, Wilson et al. 2008). For adult marine turtles, which are typically highly migratory, satellite tracking has become the method of choice to unlock the patterns of their movements (Godley et al. 2008).

Post-breeding migration in hard-shelled marine turtles has been assigned to 4 main patterns (Godley et al. 2008). The first 3 categories involve directed movement to a fixed, generally neritic feeding area. Examples of these include migratory distances ranging from a few hundred to a few thousand kilometres (e.g. green turtles Chelonia mydas: Troëng et al. 
2005, Seminoff et al. 2008; loggerhead turtles Caretta caretta: Girard et al. 2009, Zbinden et al. 2011; hawksbill turtles Eretmochelys imbricata: Van Dam et al. 2008). The final category, pelagic living, which is typical of the leatherback turtle Dermochelys coriacea (e.g. Hays et al. 2004, Luschi et al. 2006, Benson et al. 2007a) has until recently also been thought to be the main life-history strategy of the olive ridley Lepidochelys olivacea (Plotkin 2003).

Through satellite tracking, previously accepted lifehistory models for sea turtle species are being shown as oversimplifications, with considerable levels of behavioural plasticity becoming evident. As well as posing questions as to the ecological drivers of such variation, this also presents challenges for conservation management. Ontogenetic habitat shifts from oceanic to neritic habitats have been revealed as reversible for loggerhead turtles (McClellan \& Read 2007), and some populations contain mixed foraging strategies, with a proportion of the adult females remaining oceanic foragers (Hatase et al. 2002, Hawkes et al. 2006, Rees et al. 2010). Similar plasticity is also becoming evident in green turtle populations (Hatase et al. 2006, Seminoff et al. 2008). Multiple strategies during the internesting period, including oceanic looping away from the nesting beach, have also been shown for loggerheads (Blumenthal et al. 2006, Rees et al. 2010), adding further complexity to time-dependent spatial habitat use.

The most numerous globally distributed marine turtle is the olive ridley (Pritchard 1997). It has breeding populations in the western and eastern Pacific, Atlantic and Indian Oceans with several locations comprising >100000 breeding females annually (Bernardo \& Plotkin 2007). Satellite tracking of this species has begun to elucidate behavioural differences among populations. Adult females from the eastern Pacific disperse into the open ocean after breeding, as do reproductively active males (Plotkin 2010). Turtles in this area have been shown to remain in oceanic conditions (Beavers \& Cassano 1996), capable of dives to greater than $400 \mathrm{~m}$ depth (Swimmer et al. 2002 \& 2006), with indications that they are not surface feeders (Polovina et al. 2004). Conversely, adult females from northern Australia largely remain in neritic waters, preferring coastal, continental shelf habitat (McMahon et al. 2007, Whiting et al. 2007), where they are benthic divers and foragers, although this is possible at depths to $100 \mathrm{~m}$ or more (McMahon et al. 2007, Whiting et al. 2007). Adult females nesting in the east of India were shown to initially disperse into the oceanic waters of the Bay of Bengal, with the longest tracked turtle $\left(115 d_{;} n=4\right)$ spending the majority of time in that habitat (Sasamal \& Panigraphy 2006). Recent work in west Africa has shown that during the interesting period, olive ridleys have a preference for coastal neritic habitats but may subsequently venture into oceanic seas (Maxwell et al. 2011).

The olive ridley nesting aggregation at Masirah Island, Oman, was first reported in the 1970s and was indicated as unique to the Arabian region, with an estimated 150 turtles nesting annually (Ross \& Barwani 1982). Unlike the globally important nesting loggerhead aggregation that occurs at Masirah, which has received persistent tagging and tracking efforts (Baldwin \& Al Kiyumi 1999, Rees et al. 2010), olive ridleys have been subject to very limited research (see Rees \& Baker 2006), and post-breeding dispersal to long-term foraging areas has not yet been determined.

Developing regional conservation management strategies for globally distributed protected species is most effective with correct identification of regional management units (RMUs). In these circumstances, protection can be afforded to subject species in a meaningful manner based on the geographical spread of the population. A recent global analysis of marine turtle populations (Wallace et al. 2010) characterised a total of 58 RMUs for the 7 marine turtle species and highlighted our lack of knowledge through defining only putative delineations for $16 \%$ of them. Against this backdrop, to expand our knowledge on global variation in olive ridley behaviour and investigate habitat use and dispersal patterns of the regionally important population breeding at Masirah Island, we tracked adult females that were encountered nesting there.

\section{MATERIALS AND METHODS}

Argos system satellite tags were deployed on 9 nesting female olive ridley turtles (A-I) between 25 and 31 March 2008, during the peak nesting season for this population (Ross \& Barwani 1982). The turtles were located at the eastern side of the southern tip of Masirah Island, Sultanate of Oman $\left(20.20^{\circ} \mathrm{N}, 58.69^{\circ} \mathrm{E}\right.$; Fig. 1). Seven turtles (A, B, D-F, $\mathrm{H}$, I) were equipped with location-only Kiwisat 101 tags (Sirtrack) and 2 (C, G) were equipped with pressure-sensing SPLASH tags (Wildlife Computers). Devices were attached using Powerfast 2-part epoxy following established methods (Godley et al. 2002). Each turtle carapace was measured (curved carapace length, CCL; Bolten 1999), and prior to satellite tag 
attachment, each turtle was tagged on its fore flippers with uniquely numbered metal tags (Balazs 1999).

Pressure-sensing tags were configured to sample depth every $10 \mathrm{~s}$ and to convert these readings into

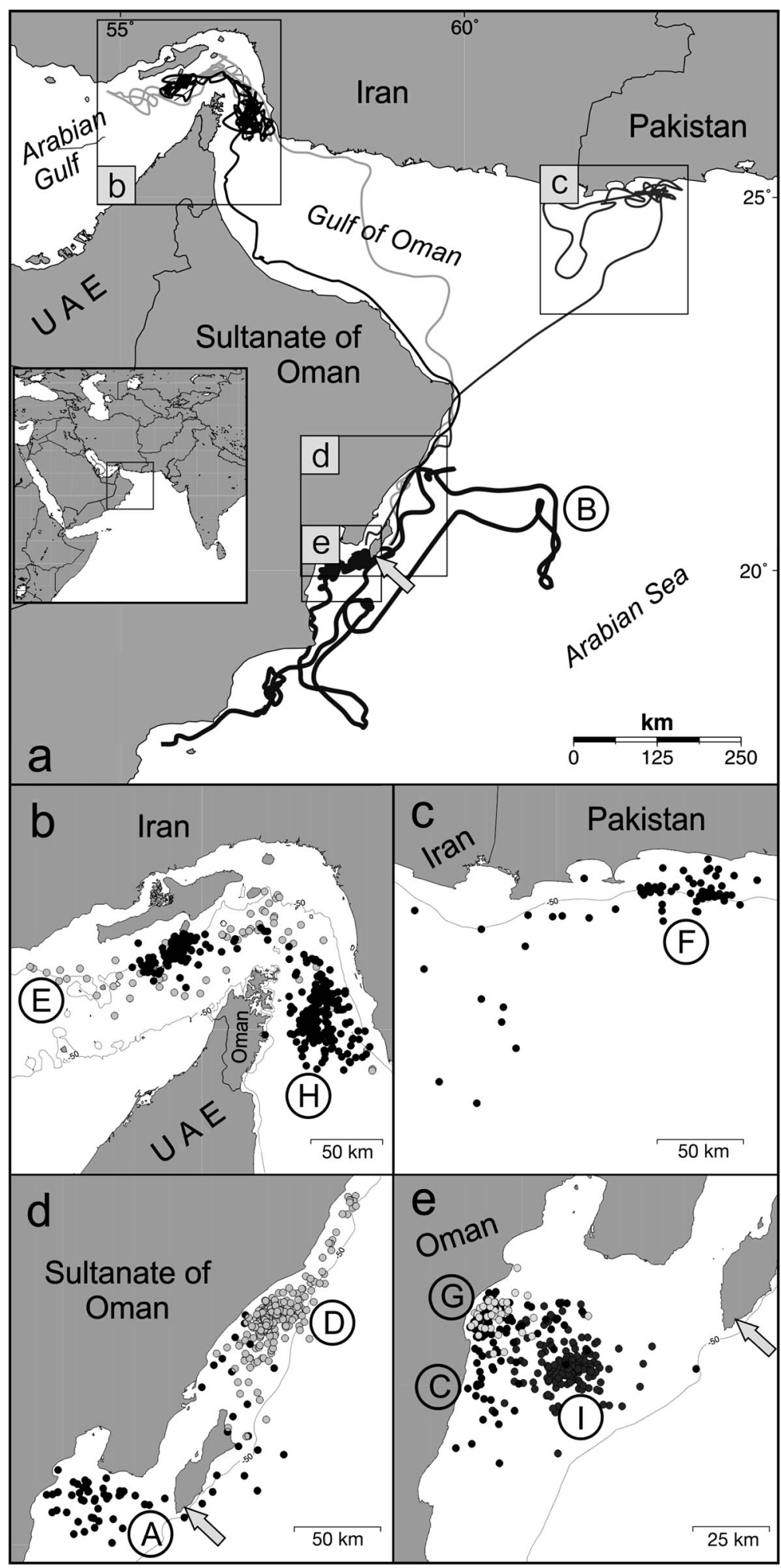

various dive parameters. Six-hourly time bins (beginning at 00:00, 06:00, 12:00 and 18:00 h local time) were used to summarise the sensor data, and the dive threshold was set at $3 \mathrm{~m}$. Absolute number of dives is reported per time bin. Depth utilisation is reported as the number of dives to maximum depths in $10 \mathrm{~m}$ bins. Dive duration is reported as the number of dives to maximum durations in 10 min bins up to $100 \mathrm{~min}$ and then to 150,200 and $>200$ min. Hourly proportion of time spent at the surface is also reported.

Argos data were downloaded, managed and analysed using the Satellite Tracking Analysis Tool (STAT; Coyne \& Godley 2005). Turtle movements were reconstructed using positions obtained from Argos Location Classes 3, 2, 1, A and B as recommended by Witt et al. (2010). Positional errors were removed by filtering locations that required maximum travelling speed $>5 \mathrm{~km} \mathrm{~h}^{-1}$ and turning angle between points of $<25^{\circ}$. Tracks were then interpolated to provide a daily location assigned to 12:00 $\mathrm{h}$ local time.

The change from internesting to postnesting status was visually determined from an individual's departure from the nesting area confirmed by its long-term displacement from the nesting site. As per Maxwell et al. (2011), location accuracy and frequency were insufficient to precisely determine nesting events. However, individual nesting periods were determined using a combination of turtle movement, absolute location, the receipt

Fig. 1. Lepidochelys olivacea. Post-breeding migrations and foraging habitat of the 9 olive ridley turtles tracked after nesting on Masirah Island, Oman. (a) Long-distance directed and wandering migrations of 4 individuals. Tracks are smoothed from daily locations to improve visual impact. The remaining 5 individuals remained local to Masirah, and their foraging movements are depicted in the lower panels: (b) 2 individuals that migrated north to the entrance of the Arabian Gulf, (c) 1 individual that migrated to the coastal waters of Pakistan, (d) habitat use north of Masirah by 2 individuals, one of which also used the Gulf of Masirah and (e) 3 individuals that exclusively used the Gulf of Masirah. Lower panels show the $50 \mathrm{~m}$ bathymetry contour. Circled letters indicate turtle IDs. Arrow indicates tagging site on Masirah Island 
of a number of high-quality Argos locations received near the nesting beach and timing, relative to known internesting periods for this species (Tucker 2010). Additionally, for the 2 depth-sensing tags, hourly percentage time at the surface was used to determine nesting activity through significantly increased surface time during the night.

\section{RESULTS}

\section{Morphometrics, tracking duration and inference of nesting periods and clutch frequency}

Mean CCL for the 9 study animals was $74.1 \mathrm{~cm}$ $(\mathrm{SD}=1.6 \mathrm{~cm}$; range 71 to $76 \mathrm{~cm})$. Average tracking duration was $211 \pm 125.2 \mathrm{~d}$ (range 72 to $459 \mathrm{~d}$; Table 1). Turtles were deemed to have finished nesting when they moved away from the original nesting area and did not return. As turtles were tagged during the peak nesting season, nesting prior to tag deployment was highly likely. Turtles D and I (Fig. 2a) departed immediately after tagging and therefore laid a minimum of 1 nest. Turtles E, G, and $\mathrm{H}$ (Fig. 2b) initially migrated more than $50 \mathrm{~km}$ from origin (= tagging site $=$ nesting site) prior to returning for a variable length of time before nesting again and final departure, thus nesting at least twice. Turtles A and C (Fig. 2c) initially departed, but returned after approximately $18 \mathrm{~d}$. However, only Turtle C was inferred to have re-nested. The movement of Turtle A, initially north of Masirah, indicated that it bypassed southern Masirah on its way to the Gulf of Masirah foraging habitat. Turtles B and F (Fig. 2a) remained within $40 \mathrm{~km}$ of origin for 27 and $38 \mathrm{~d}$, respectively, before permanent departure. Turtle B was inferred to have re-nested once and Turtle $\mathrm{F}$ twice. A summary of clutch frequency values (number of nests laid per individual) is found in Table 1.

\section{Internesting habitat use}

All turtles that re-nested subsequent to transmitter deployment $(\mathrm{N}=6)$ utilised the shallow waters (<40 m depth) of the Gulf of Masirah as internesting habitat (Fig. 3). Mean maximum displacement from initial nesting location during the internesting period was $59 \mathrm{~km}$ (range 29 to $75 \mathrm{~km}$ ). All nests were made at the southern tip of Masirah Island (ca. $13 \mathrm{~km}$ of nesting beach), but no precise measure of nest site fidelity was possible due to data limitations.

\section{Post-nesting dispersal}

Broadly speaking, 4 geographically distinct foraging habitats were identified for olive ridley turtles outside of the breeding season (Fig. 1). North to south these were (1) entrance to the Arabian Gulf (Turtles E and H), (2) coastal waters of western Pakistan (Turtle F), (3) Omani coastal waters north of Masirah (Turtle D) and (4) the Gulf of Masirah, which was also the internesting habitat (Turtles A, C, G, I). These predominantly neritic locations accounted for 8 of the 9 individuals (with 1 individual, Turtle A, using both foraging areas proximate to Masirah). The last individual (Turtle B) remained within Omani seas but was a persistent wanderer, spending a significant portion of time (39\% of days with data) in oceanic waters $(>200 \mathrm{~m})$. Post-breeding turtle displacement clearly shows the variation in migratory distance

Table 1. Lepidochelys olivacea. Individual size, nesting and tracking characteristics for the 9 study animals. CCL: curved carapace length; CF: inferred minimum clutch frequency; max. displ.: maximum displacement from tagging site; duration: duration of tracking; data days: number of days with location data from total number of days in foraging area (percentage in parentheses) $;<200 \mathrm{~m}$ : proportion of days spent in waters less than $200 \mathrm{~m}$ deep; $<50 \mathrm{~m}$ : proportion of days spent in waters less than $50 \mathrm{~m}$ deep. Turtles $\mathrm{C}$ and $\mathrm{G}$ were equipped with pressure-sensing tags

\begin{tabular}{|c|c|c|c|c|c|c|c|c|}
\hline $\begin{array}{l}\text { Turtle } \\
\text { ID }\end{array}$ & $\begin{array}{l}\mathrm{CCL} \\
(\mathrm{cm})\end{array}$ & $\begin{array}{c}\mathrm{CF} \\
\text { (nests) }\end{array}$ & $\begin{array}{l}\text { Max. displ. } \\
(\mathrm{km})\end{array}$ & $\begin{array}{l}\text { Duration } \\
\text { (d) }\end{array}$ & $\overline{\text { Data days (\%) }}$ & $\begin{array}{r}\text { raging areas } \\
<200 \mathrm{~m}(\%)\end{array}$ & $\overline{<50 \mathrm{~m} \mathrm{( \% )}}$ & Terminus \\
\hline A & 74.5 & 1 & 120 & 74 & 71/74 (95.9) & 94 & 86 & Oman \\
\hline B & 75 & 2 & 434 & 255 & $182 / 227(80.2)$ & 61 & 34 & Oman \\
\hline $\mathrm{C}$ & 76 & 2 & 101 & 136 & $100 / 117(85.5)$ & 100 & 100 & Oman \\
\hline $\mathrm{D}$ & 71 & 1 & 204 & 314 & $225 / 310(72.6)$ & 100 & 95 & Oman \\
\hline $\mathrm{E}$ & 74 & 2 & 796 & 145 & 68/82 (82.9) & 100 & 19 & Iran \\
\hline F & 72.5 & 3 & 714 & 178 & $80 / 113(70.8)$ & 88 & 65 & Pakistan \\
\hline $\mathrm{G}$ & 76 & 2 & 87 & 71 & $39 / 40(97.5)$ & 100 & 100 & Oman \\
\hline $\mathrm{H}$ & 73.5 & 2 & 775 & 462 & $306 / 398(76.9)$ & 100 & 11 & Iran \\
\hline I & 74.5 & 1 & 85 & 261 & $172 / 260(66.2)$ & 100 & 93 & Oman \\
\hline
\end{tabular}


travelled, with average maximum distance from origin of $368 \mathrm{~km}$ (range 85 to $796 \mathrm{~km}, \mathrm{n}=9$; Table 1, Fig. 1). Excluding the more oceanic turtle (Turtle $B_{\text {; }}$ Fig. 1a), the remaining turtles can be grouped according to their location and distance migrated. Turtles that migrated over $450 \mathrm{~km}$ all went north $(\mathrm{n}=3$; Fig. $1 \mathrm{~b}, \mathrm{c})$, with the remaining turtles remaining near
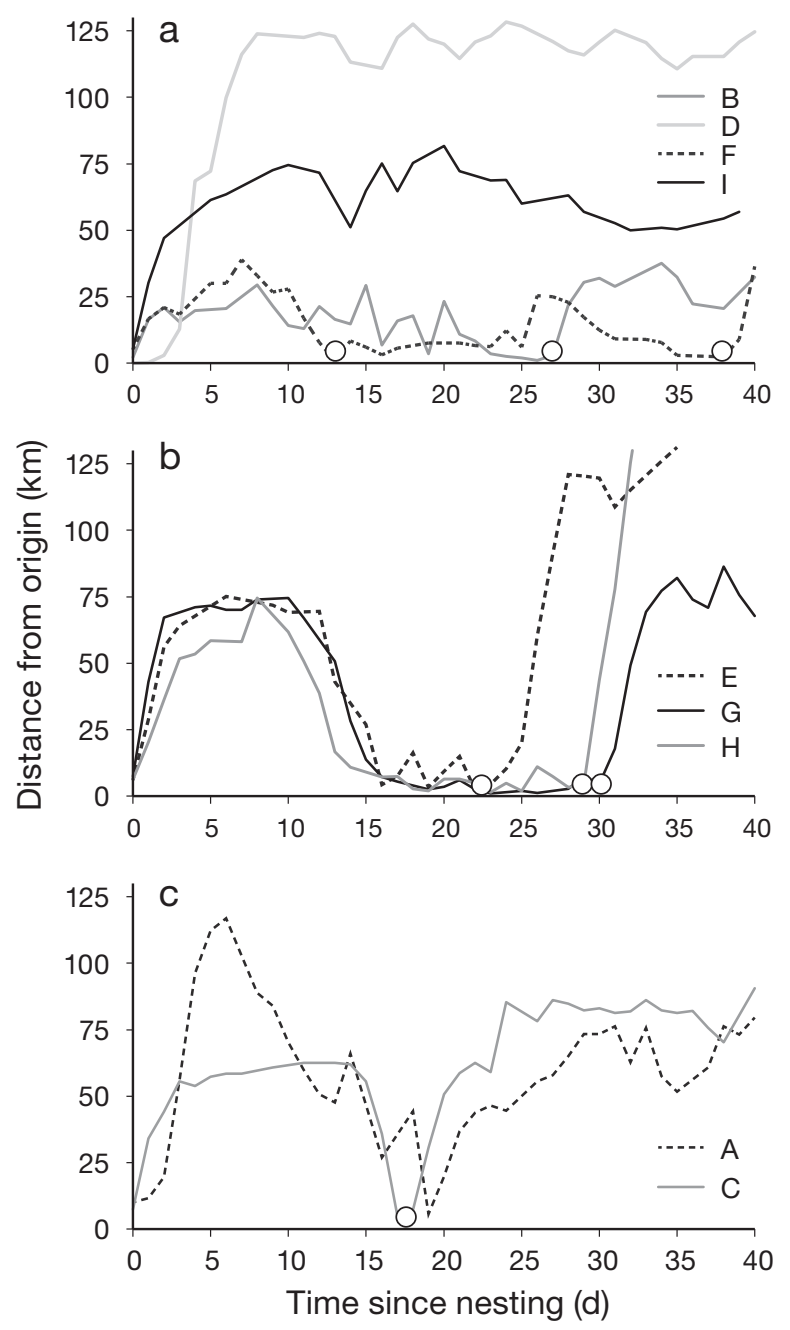

Fig. 2. Lepidochelys olivacea. Displacement from nesting site (origin) during potential nesting period. (a) Individuals that either departed immediately and did not return, i.e. they were recorded nesting once, or remained within $50 \mathrm{~km}$ of the nesting area for an extended period, which would facilitate nesting once or twice more. (b) Individuals that returned after approximately $16 \mathrm{~d}$ and remained close to the nesting area for between 1 and 2 wk before departure; this was interpreted as further nesting after protracted nest site searching. (c) Individuals that returned after 17 and $19 \mathrm{~d}$ and immediately departed; this was interpreted as possibly nesting a subsequent time. However, Turtle A was thought not to re-nest, as it was constantly wandering and coincidentally passed the nesting site during the potential internesting period. Open circles indicate inferred nesting events
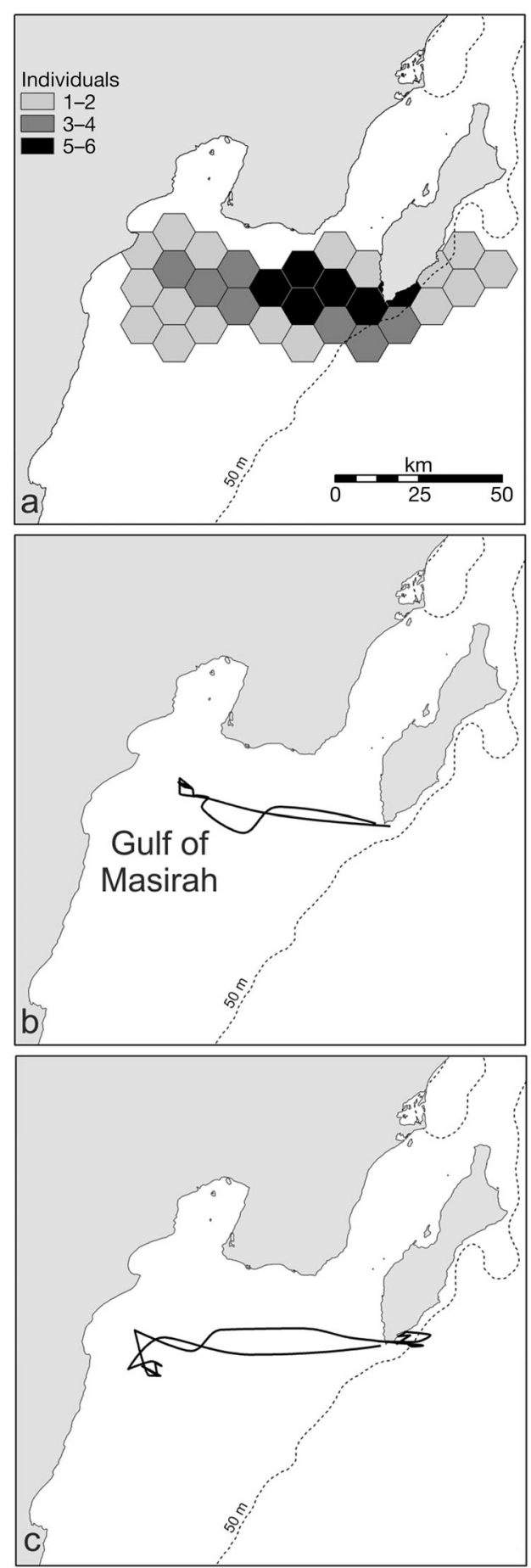

Fig. 3. Lepidochelys olivacea. Internesting habitat from daily interpolated locations (see 'Materials and methods') for the 6 turtles inferred to have re-nested after transmitter deployment (B, C, E, F, G, H). (a) Hexagonal utilisation plot of the number of turtles per area. $(b, c)$ Examples of internesting tracks showing directed movements away from and towards the nesting location for Turtles $\mathrm{C}$ and $\mathrm{G}$, respectively. The $50 \mathrm{~m}$ bathymetry contour is depicted in all panels (dashed line). All turtles mainly remained within the nearby shallow waters of the Gulf of Masirah 
the southern nesting habitat $(\mathrm{n}=5$; Fig. $1 \mathrm{~d}, \mathrm{e})$. The single turtle tracked for $>1 \mathrm{yr}$ (Turtle $\mathrm{H}$ ) did not show an annual return to the nesting area.

We investigated whether turtle size was related to foraging location, initially driven by the observation that the smallest turtle (D) was the only one that exhibited dense algal growth over the carapace during nesting and was the only individual that went on to inhabit mainland coastal waters north of Masirah. We compared carapace size between northern $(\mathrm{E}, \mathrm{F}$, $\mathrm{H}_{i}$ median $\left.\mathrm{CCL}=73.5 \mathrm{~cm}\right)$ and southern $(\mathrm{A}, \mathrm{C}, \mathrm{D}, \mathrm{G}$, $\mathrm{I}_{\text {; }}$ median $\mathrm{CCL}=75.3 \mathrm{~cm}$ ) turtles and found the southern ones were significantly larger (Mann-Whitney $U=0.0, \mathrm{p}<0.05)$.

\section{Foraging habitat selection}

All turtles remained in neritic water for the majority of the time they were tracked in foraging areas (range 61 to $100 \%$ ). Although foraging could have taken place during the migration phase, 'foraging areas' were defined as the approximate regions where directed migrations ceased and were replaced by more convoluted tracks (McMahon et al. 2007; Fig. 1). Turtle B never properly settled (Fig. 1a), and the entire post-breeding track was included as its foraging area. Locally resident turtles (A, C, D, G, I; Fig. 1d,e) showed a preference for extremely shallow seas, located in water $<50 \mathrm{~m}$ deep for upwards of $85 \%$ of the foraging period. Turtle $F$, which migrated to Pakistan (Fig. 1C) displayed a similar preference for shallow seas but undertook an oceanic loop during the foraging period. The 2 turtles ( $\mathrm{F}$ and $\mathrm{H}$ ) that migrated to the entrance of the Arabian Gulf (Fig. 1b) mainly resided in intermediate sea depths (Table 1).

The northern turtles (see above) avoided the summer cooling that occurs along the Oman coast, caused by the southwest monsoon and the west Arabian Sea upwelling, whereas the southern turtles experienced a biannual oscillation (Fig. 4).

\section{Dive data}

Dive data were obtained from Turtles $\mathrm{C}$ and $\mathrm{G}$ for 136 and $72 \mathrm{~d}$, respectively. Both turtles re-nested after initial tag deployment, and hence both internesting and post-nesting behaviour were obtained. They utilised a similar area for the internesting and post-breeding phase of tracking.

Overall, the turtles were shown to inhabit the full range of depth available to them, residing in ex-

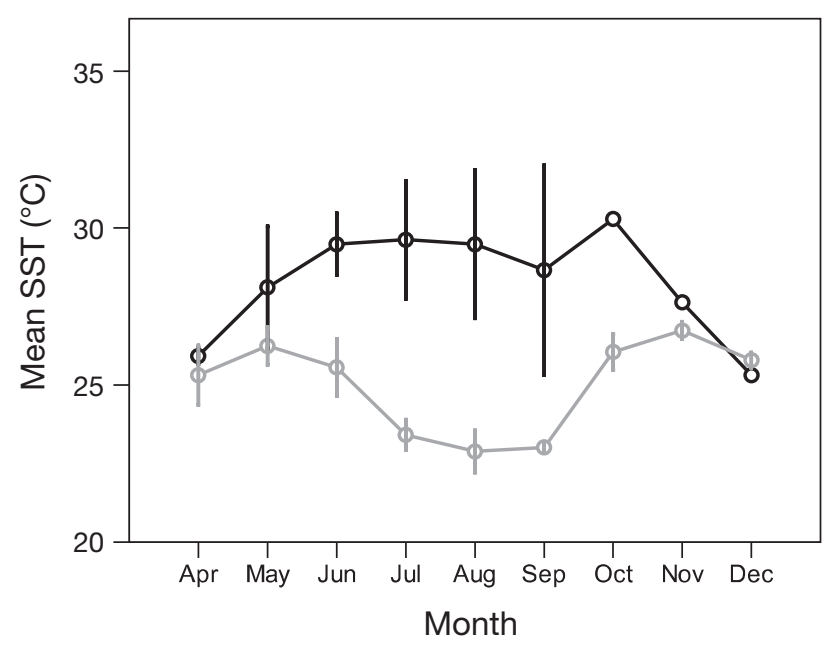

Fig. 4. Lepidochely olivacea. Sea surface temperature (SST) variation experienced by turtles at different localities. Southern individuals (Turtles A, C, D, G, I; grey line, max. $n$ $=5$ ) experience cooled monsoon seas during the summer that are not experienced by the northern individuals (Turtles $\mathrm{E}, \mathrm{F}, \mathrm{H}$; black line, max. $\mathrm{n}=3$ ). Error bars $\pm 1 \mathrm{SD}$

tremely shallow coastal waters. The low number of dives to depths greater than $30 \mathrm{~m}$ is interpreted as being location limited, as sea depths in the area occupied rarely exceeded $30 \mathrm{~m}$. Many of the shallower dives were assumed to be bottom dives and not a preference for mid-water diving. Both turtles displayed a shift in preference from dives between 20 and $30 \mathrm{~m}$ during the internesting period to shallower 10 to $20 \mathrm{~m}$ dives in the post-nesting period (Fig. 5) as they generally moved closer to shore (compare internesting locations in Fig. 3b,c with post-nesting locations in Fig. 1e).

Both Turtles C and G exhibited a preference for longer dives during the internesting period, with median values of 70 and $60 \mathrm{~min}$, which shortened to 30 and $20 \mathrm{~min}$, respectively, after the breeding period (Fig. 6). Notably, the turtles were capable of extended dives of over 100 min while inhabiting shallow (see Fig. 5) and warm (see Fig. 4) seas, with maximum dive duration for both turtles occurring in the 150 to $200 \mathrm{~min}$ and 100 to $150 \mathrm{~min}$ time bins for Turtles C and G, respectively (Fig. 6).

\section{DISCUSSION}

As with many previous tracking studies, this work quickly revealed significant insights into the ecology of this population. Firstly, we demonstrate a degree of variability in the duration of internesting periods 

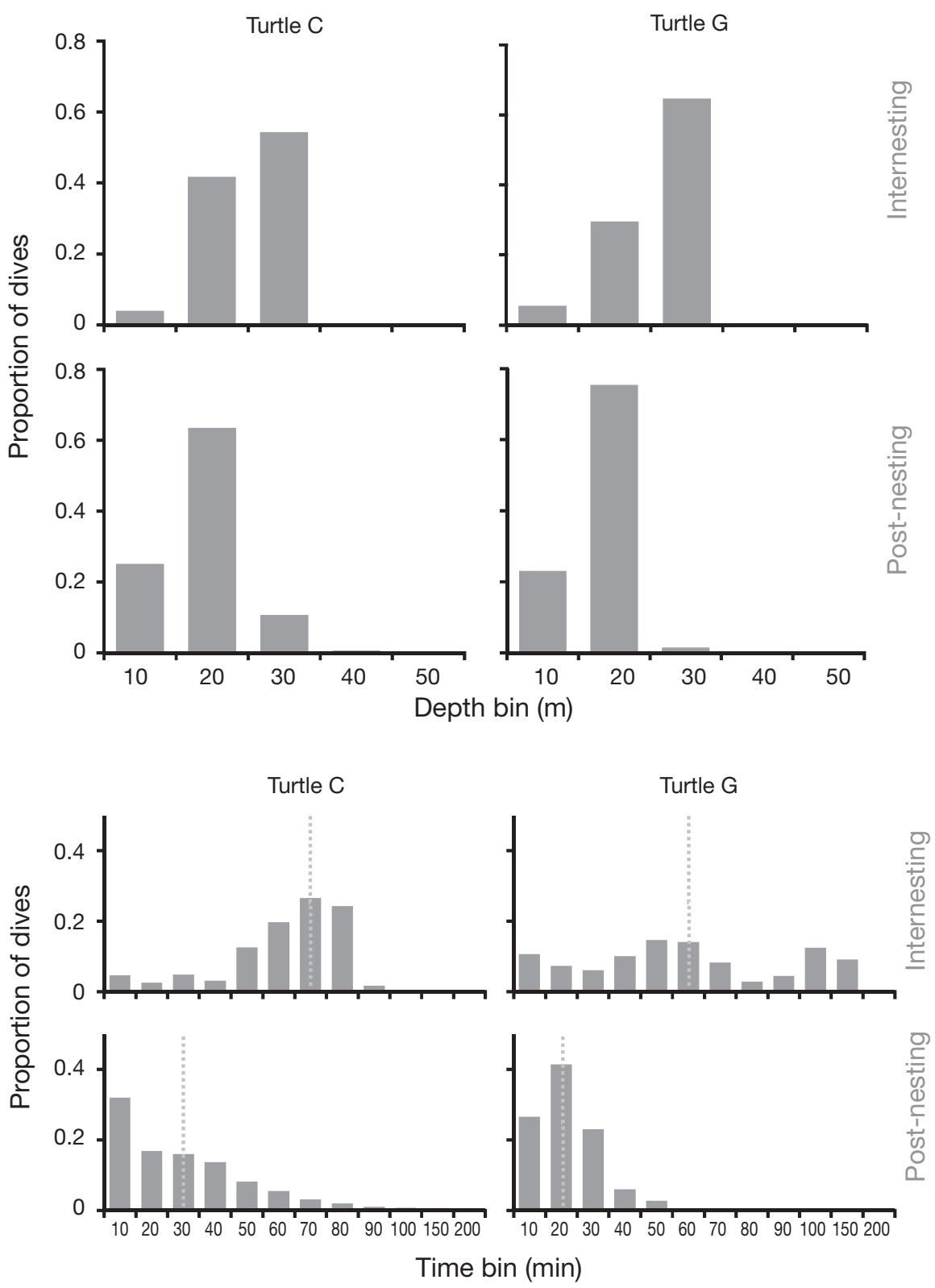

Fig. 5. Lepidochelys olivacea. Proportion of dives per depth bin for Turtles C and G. Both turtles showed a shift to shallower dives after the breeding season. At all times, these turtles were depth limited by their surroundings, as they were in locations $<40 \mathrm{~m}$ deep

Fig. 6. Lepidochelys olivacea. Proportion of dives per duration bin for Turtles C and G. Both turtles showed a shift from longer dives during the internesting period to shorter dives after breeding; this was interpreted as switching from a more sedentary, internesting period to a greater level of activity afterwards. Vertical dashed lines indicate median dive duration bin

(Fig. 2), which concurs with data from other nesting populations (see Whiting et al. 2007, Hamel et al. 2008, Tripathy \& Pandav 2008 and references therein, Maxwell et al. 2011), indicating that in this species the internesting period is less tied to direct physiological development of the eggs but is likely more dependent on environmental cues (Plotkin et al. 1997). The noted change to shorter dives after breeding is interpreted as a change from sedentary behaviour in the internesting period to greater activity post breeding, as has been shown for other turtle species (Hays et al. 1999, Houghton et al. 2002) and relates to the relationship between dive depths, oxygen stores and activity levels (Hays et al. 2000).
Outside the breeding season, the turtles displayed a distinct preference for shallow coastal seas and as such are aligned with the habitat selection of conspecifics from northern Australia (McMahon et al. 2007, Whiting et al. 2007) rather than the eastern Pacific (Polovina et al. 2004, Plotkin 2010), eastern Atlantic (Maxwell et al. 2011) and northern Indian Ocean (Sasamal \& Panigraphy 2006) populations that appear to generally prefer oceanic habitats.

Except for Plotkin (2010) and Maxwell et al. (2011), results, including this study, have been obtained with relatively small sample sizes ( $\mathrm{n}=4$ to 9 ) carried out in a single year. Dispersal patterns from nesting beaches may vary among years (Rees et al. 2010, Witt 
et al. 2011). Turtles in a particular season's breeding cohort are composed of mixed proportions of turtles derived from differing foraging locations, with remigration rates driven by variation in local environmental conditions in the foraging grounds (Broderick et al. 2001, Hays 2000, Hatase et al. 2004, Solow et al. 2002). Consequently, further efforts are needed to confirm how typical the movements of our 9 study animals are.

Turtle behaviour derived from depth-sensing tags suggested they were benthic divers. Dive characteristics for most hard-shelled sea turtles are related to aerobic limits, showing longer-duration dives possible in colder water (Southwood et al. 2003, Broderick et al. 2007, Hochscheid et al. 2007), due to thermal dependence of metabolism, and a positive relationship between dive depth and maximum dive duration (Hays et al. 2000, Houghton et al. 2000). However, olive ridley turtles from Australia have been shown to have unusual dive characteristics, capable of dives in excess of $3 \mathrm{~h}$ in warm seas (McMahon et al. 2007). Our study animals were also able to undertake dives of extended duration (>150 min) in warm shallow waters, which adds further evidence supporting the unique diving abilities of this species.

Individuals displayed low to moderate migratory distances when compared to conspecifics from other populations (e.g. Pandav \& Choudhury 2006, McMaon et al. 2007, Plotkin 2010). The Gulf of Masirah, less than $150 \mathrm{~km}$ from the nesting area, was identified as a key foraging habitat both during and after the breeding season. Tracking durations ranging from 71 to $261 \mathrm{~d}$ revealed this to be the sole foraging location for 3 of the study turtles $(C, G, I)$ and was also frequented by 2 other individuals (A and B). This contrasts with movements of females from the much larger population of loggerhead turtles nesting on Masirah Island that did not use this gulf (Rees et al. 2010). Although our results are from only $1 \mathrm{yr}$ of tracking, this site can clearly be identified as a 'hot spot' for olive ridleys nesting in Oman and warrants further study concerning threats to resident turtles.

There may be a correlation between foraging grounds and body size in the study population. Previous studies have revealed size dichotomies in populations of other sea turtle species at the ocean basin level (e.g. leatherback, Saba et al. 2008 and loggerhead turtles, Margaritoulis et al. 2003), between foraging habitat types (loggerheads in oceanic and neritic habitats; Hatase et al. 2002, Hawkes et al. 2006) and between differing neritic habitats (loggerheads, Zbinden et al. 2011).
Our results revealed indications of differences in body size between southern and northern turtles that may result from the effects of environmental factors. Larger, southern turtles experience cooler summer seas caused by the southwest monsoon and the west Arabian Sea upwelling that affect sea productivity and consequently prey abundance. This is the first time that intrapopulation phenotypic differences have been suggested for olive ridleys; however, our small sample size necessarily implies that inferences should be accepted with caution. Further satellite tracking and possible scaling-up through stable isotope analysis, as used by Zbinden et al. (2011), may provide further insights into the interplay of behaviour and phenotypic variation within the population. Two aspects of the dispersal patterns demonstrated are worthy of note. Firstly, despite nesting in the same area as an important loggerhead turtle nesting aggregation, the 2 species used different core foraging habitats. The loggerheads mostly migrated to the oceanic region between the Yemen and Oman coastline and the Island of Socotra over $800 \mathrm{~km}$ distant from Masirah (Rees et al. 2010). If the oceanic waters of the Arabian Sea are sufficient to sustain a large population of loggerhead turtles, then conditions should be suitable for the smaller olive ridley that has been shown to inhabit similar habitat in the eastern tropical Pacific and western Indian Ocean. Secondly, for reasons unknown, neither the loggerheads nor the olive ridleys from Masirah Island have so far been observed to migrate eastwards to India across the Arabian Sea, a feat that is within the capabilities of both.

In total, 6 of the 9 turtles tracked remained within Oman's territorial jurisdiction, which indicates the country's unique role in managing and protecting the adult stage of this population. Nevertheless, the northern turtles settled for extended periods in the territorial waters of Pakistan, Iran and the United Arab Emirates, revealing that, as for most marine turtle populations (e.g. Troëng et al. 2005, Blumenthal et al. 2006, Benson et al. 2007b), conservation and management activities for single populations may be more effective if they involve actions in multiple range states.

Having established the spatial footprint for nesting olive ridleys that highlights a very limited distribution, we can conclude that the turtles are likely susceptible to bycatch in regional fisheries that have been identified as the source of hundreds of turtle deaths within the country (Hare 1991). In addition to larger-vessel, industrial fishing fleet interactions, the population is likely to be impacted upon by coastal 
artisanal fisheries that are poorly documented but are cause for concern elsewhere (e.g. Peckham et al. 2007, Alfaro-Shigueto et al. 2011).

We present the first results on migrations and behaviour of olive ridleys nesting in Oman, filling a void in the life-history data of this important population in one of the globally most endangered sea turtle RMUs (Wallace et al. 2011). Understanding such spatial movements has been highlighted as a research priority (Hamann et al. 2010). In this context, we found the distribution of our study animals to lie within the spread of the putative boundary of the west Indian Ocean RMU (Wallace et al. 2010), therefore supporting its current delineation.

In this study, we have described movements of adult female individuals. Male turtles may have different dispersal characteristics (Plotkin et al. 1996, Van Dam et al. 2008, Hays et al. 2010) and thus warrant dedicated tracking efforts (Godley et al. 2008). Additional tracking studies from the different nesting populations in the region, together with genetic characterisation of these populations and animals obtained at sea are necessary to firmly define this RMU and hence provide a biologically relevant basis for regional conservation actions.

Acknowledgements. We thank M. Georgomitrou and the Wildlife Rangers of Masirah for assistance in deploying the transmitters. The project was co-funded by the TOTAL Foundation for Biodiversity and the Environment and TOTAL Oman SA (Muscat Branch). A.C.B. and B.J.G. are funded by the Darwin Initiative and NERC. The base maps for Fig. 1 were created using MapTool (a free mapping tool from www.seaturtle.org), and M. Witt helped produce the maps for Fig. 3. This paper was greatly improved thanks to the feedback from 3 anonymous reviewers.

\section{LITERATURE CITED}

Alfaro-Shigueto J, Mangel JC, Bernedo F, Dutton PH, Seminoff JA, Godley BJ (2011) Small-scale fisheries of Peru: a major sink for marine turtles in the Pacific. J Appl Ecol 48:1432-1440

Baker CS, Palumbi SR, Lambertsen RH, Weinrich MT, Calambokidas J, O'Brien SJ (1990) Influence of seasonal migration on geographic distribution of mitochondrial DNA haplotypes in humpback whales. Nature 344: 238-240

Balazs GH (1999) Factors to consider in the tagging of sea turtles. In: Eckert KL, Bjorndal KA, Abreu-Grobois FA, Donnelly M (eds) Research and management techniques for the conservation of sea turtles. IUCN/SSC Marine Turtle Specialist Group Publication No. 4, Washington, DC, p 101-109

Baldwin RM, Al Kiyumi ABA (1999) The ecology and conservation status of sea turtles of Oman. In: Fisher M, Ghazanfar SA, Spalton JA (eds) The natural history of Oman: a Festschrift for Michael Gallagher. Backhuys Publish- ers, Leiden, p 89-98

Beavers SC, Cassano ER (1996) Movements and dive behavior of a male sea turtle (Lepidochelys olivacea) in the Eastern Tropical Pacific. J Herpetol 30:97-104

> Benson SR, Kisokau KM, Ambio L, Rei V, Dutton PH, Parker D (2007a) Beach use, internesting movement, and migration of leatherback turtles, Dermochelys coriacea, nesting on the north coast of Papua New Guinea. Chelonian Conserv Biol 6:7-14

> Benson SR, Dutton PH, Hitipeuw C, Samber B, Bakarbessy J, Parker D (2007b) Post-nesting migrations of leatherback turtles (Dermochelys coriacea) from JamursbaMedi, Bird's Head Peninsula, Indonesia. Chelonian Conserv Biol 6:150-154

Bernardo J, Plotkin PT (2007) An evolutionary perspective on the arribada phenomenon and reproductive behavioural polymorphism of olive ridley sea turtles (Lepidochelys olivacea). In: Plotkin PT (ed) Biology and conservation of ridley sea turtles. Johns Hopkins University Press, Baltimore, MD, p 59-87

Block BA, Dewar H, Blackwell SB, Williams TD and others (2001) Migratory movements, depth preferences, and thermal biology of Atlantic bluefin tuna. Science 293: 1310-1314

Blumenthal JM, Solomon JL, Bell CD, Austin TJ and others (2006) Satellite tracking highlights the need for international cooperation in marine turtle management. Endang Species Res 2:51-61

Bolten AB (1999) Techniques for measuring sea turtles. In: Eckert KL, Bjorndal KA, Abreu-Grobois FA, Donnelly M (eds) Research and management techniques for the conservation of sea turtles. IUCN/SSC Marine Turtle Specialist Group Publication No. 4, Washington, DC, p 110-115

> Broderick AC, Godley BJ, Hays GC (2001) Trophic status drives interannual variability in nesting numbers of marine turtles. Proc R Soc Lond B Biol Sci 268:1481-1487

> Broderick AC, Coyne MS, Fuller WJ, Glen F, Godley BJ (2007) Fidelity and overwintering of sea turtles. Proc R Soc Lond B Biol Sci 274:1533-1538

Coyne MS, Godley BJ (2005) Satellite tracking and analysis tool (STAT): an integrated system for archiving, analyzing and mapping animal tracking data. Mar Ecol Prog Ser 301:1-7

Girard C, Tucker AD, Calmettes B (2009) Post-nesting migrations of loggerhead sea turtles in the Gulf of Mexico: dispersal in highly dynamic conditions. Mar Biol 156:1827-1839

Godley BJ, Richardson S, Broderick AC, Coyne MS, Glen F, Hays GC (2002) Long-term satellite telemetry of the movements and habitat utilisation by green turtles in the Mediterranean. Ecography 25:352-362

> Godley BJ, Blumenthal JM, Broderick AC, Coyne MS, Godfrey MH, Hawkes LA, Witt MJ (2008) Satellite tracking of sea turtles: Where have we been and where do we go next? Endang Species Res 4:3-22

Hamann M, Godfrey MH, Seminoff JA, Arthur K and others (2010) Global research priorities for sea turtles: informing management and conservation in the 21st century. Endang Species Res 11:245-269

> Hamel MA, McMahon CR, Bradshaw CJA (2008) Flexible inter-nesting behaviour of generalist olive ridley turtles in Australia. J Exp Mar Biol Ecol 359:47-54

Hare SR (1991) Turtles caught incidental to demersal finfish fishery in Oman. Mar Turtle Newsl 53:14-16 
Hatase H, Takai N, Matsuzawa Y, Sakamoto W and others (2002) Size-related differences in feeding habitat use of adult female loggerhead turtles Caretta caretta around Japan determined by stable isotope analyses and satellite telemetry. Mar Ecol Prog Ser 233:273-281

Hatase H, Matsuzawa Y, Sato K, Bando T, Goto K (2004) Remigration and growth of loggerhead turtles (Caretta caretta) nesting on Senri Beach in Minabe, Japan: lifehistory polymorphism in a sea turtle population. Mar Biol 144:807-811

Hatase H, Sato K, Yamaguchi M, Takahashi K, Tsukamoto K (2006) Individual variation in feeding habitat use by adult female green sea turtles (Chelonia mydas): Are they obligately neritic herbivores? Oecologia 149:52-64

> Hawkes LA, Broderick AC, Coyne MS, Godfrey MS and others (2006) Phenotypically linked dichotomy in sea turtle foraging requires multiple conservation approaches. Curr Biol 16:990-995

Hays GC (2000) The implications of variable remigration intervals for the assessment of population size in marine turtles. J Theor Biol 206:221-227

> Hays GC, Luschi P, Papi F, del Seppia C, Marsh R (1999) Changes in behaviour during the inter-nesting period and post-nesting migration for Ascension Island green turtles. Mar Ecol Prog Ser 189:263-273

Hays GC, Hochscheid S, Broderick AC, Godley BJ, Metcalfe JD (2000) Diving behaviour of green turtles: dive depth, dive duration and activity levels. Mar Ecol Prog Ser 208: 297-298

Hays GC, Houghton JDR, Myers AE (2004) Endangered species: pan-Atlantic leatherback turtle movements. Nature 429:522

> Hays GC, Fossette S, Katselidis KA, Schofield G, Gravenor MB (2010) Breeding periodicity for male sea turtles, operational sex ratios, and implications in the face of climate change. Conserv Biol 24:1636-1643

> Hochscheid S, Bentivegna F, Bradai MN, Hays GC (2007) Overwintering behaviour in sea turtles: dormancy is optional. Mar Ecol Prog Ser 340:287-298

Houghton JDR, Woolmer A, Hays GC (2000) Sea turtle diving and foraging behaviour around the Greek island of Kefalonia. J Mar Biol Assoc UK 80:761-762

Houghton JDR, Broderick AC, Godley BJ, Metcalfe JD, Hays GC (2002) Diving behaviour during the internesting interval for loggerhead turtles Caretta caretta nesting in Cyprus. Mar Ecol Prog Ser 227:63-70

Luschi P, Lutjeharms JRE, Lambardi P, Mencacci R, Hughes GR, Hays GC (2006) A review of migratory behaviour of sea turtles off southeastern Africa. S Afr J Sci 102:51-58

Margaritoulis D, Argano R, Baran I, Bentivegna F and others (2003) Loggerhead turtles in the Mediterranean Sea: present knowledge and conservation perspectives. In Bolten AB, Witherington BE (eds) Loggerhead sea turtles. Smithsonian Books, Washington, DC, p 175-198

- Maxwell SM, Breed GA, Nickel BA, Makanga-Bahouna J and others (2011) Using satellite tracking to optimize protection of long-lived marine species: olive ridley sea turtle conservation in central Africa. PLoS One 6:e19905

McClellan CM, Read AJ (2007) Complexity and variation in loggerhead sea turtle life history. Biol Lett 3:592-594

> McMahon CR, Bradshaw CJA, Hays GC (2007) Satellite tracking reveals unusual diving characteristics for a marine reptile, the olive ridley turtle Lepidochelys olivacea. Mar Ecol Prog Ser 329:239-252

Pandav B, Choudhury BC (2006) Migration and movement of olive ridleys along the east coast of India. In: Shanker K, Choudhury BC (eds) Marine turtles of the Indian subcontinent. Universities Press, Hyderabad, p 365-379

> Peckham SH, Maldonado Diaz D, Walli A, Ruiz G, Crowder LB, Nichols WJ (2007) Small-scale fisheries bycatch jeopardizes endangered pacific loggerhead turtles. PLoS One 2:e1041

Plotkin P (2003) Adult migrations and habitat use. In: Lutz PL, Musick JA, Wyneken J (eds) The biology of sea turtles, Vol 2. CRC Marine Science Series. CRC Press, Boca Raton, FL, p 225-241

Plotkin PT (2010) Nomadic behaviour of the highly migratory olive ridley sea turtle Lepidochelys olivacea in the eastern tropical Pacific Ocean. Endang Species Res 13: 33-40

Plotkin P, Owens D, Byles R, Patterson R (1996) Departure of male olive ridley turtles (Lepidochelys olivacea) from a nearshore breeding ground. Herpetologica 52:1-7

Plotkin PT, Rostal DC, Byles RA, Owens DW (1997) Reproductive and developmental synchrony in female Lepidochelys olivacea. J Herpetol 31:17-22

Polovina JJ, Balazs GH, Howell EA, Parker DM, Seki MP, Dutton PH (2004) Forage and migration habitat of loggerhead (Caretta caretta) and olive ridley (Lepidochelys olivacea) sea turtles in the central North Pacific Ocean. Fish Oceanogr 13:36-51

Pritchard PCH (1997) Evolution, phylogeny and current status. In: Lutz PL, Musick JA (eds) The biology of sea turtles. CRC Marine Science Series. CRC Press, Boca Raton, FL, p 1-28

Rees AF, Baker SL (2006) Hawksbill and olive ridley nesting on Masirah Island, Sultanate of Oman: an update. Mar Turtle Newsl 113:2-5

Rees AF, Al Saady S, Broderick AC, Coyne MS, Papathanasopoulou N, Godley BJ (2010) Behavioural polymorphism in one of the world's largest populations of loggerhead sea turtles Caretta caretta. Mar Ecol Prog Ser 418: 201-212

Ross JP, Barwani MA (1982) Review of sea turtles in the Arabian area. In: Bjorndal KA (ed) Biology and conservation of sea turtles. Smithsonian Institution Press, Washington, DC, p 373-383

Saba VS, Spotilla JR, Chavez FP, Musick JA (2008) Bottomup and climatic forcing on the worldwide population of leatherback turtles. Ecology 89:1414-1427

> Sasamal SK, Panigraphy RC (2006) Influence of eddies on the migratory routes of the sea turtles in the Bay of Bengal. Int J Remote Sens 27:3115-3122

Seminoff JA, Zárate P, Coyne MS, Foley DG, Parker D, Lyon B, Dutton PH (2008) Post-nesting migrations of Galápagos green turtles, Chelonia mydas, in relation to oceanographic conditions: integrating satellite telemetry with remotely sensed ocean data. Endang Species Res 4:57-72

Solow AR, Bjorndal KA, Bolten AB (2002) Annual variation in nesting numbers of marine turtles: the effect of sea surface temperature on remigration intervals. Ecol Lett 5: 742-746

Southwood AL, Reina RD, Jones VS, Jones DR (2003) Seasonal diving patterns and body temperatures of juvenile green turtles at Heron Island, Australia. Can J Zool 81: 1014-1024

Swimmer YJ, Brill RW, Musyl M (2002) Use of pop-up satellite archival tags to quantify mortality of marine turtles incidentally captured in longline fishing gear. Mar Turtle Newsl 97:3-7 
Swimmer Y, Arauz R, McCracken M, MNaughton L and others (2006) Diving behavior and delayed mortality of olive ridley sea turtles Lepidochelys olivacea after their release from longline fishing gear. Mar Ecol Prog Ser 323:253-261

Tripathy B, Pandav B (2008) Beach fidelity and internesting movements of olive ridley turtles (Lepidochelys olivacea) at Rushikulya, India. Herpetol Conserv Biol 3:40-45

Troëng S, Evans DR, Harrison E, Lagueux CJ (2005) Migration of green turtles Chelonia mydas from Tortuguero, Costa Rica. Mar Biol 148:435-447

Tuck GN, Polacheck T, Croxall JP, Weimerskirch H (2001) Modelling the impact of fishery by-catches on albatross populations. J Appl Ecol 38:1182-1196

> Tucker AD (2010) Nest site fidelity and clutch frequency of loggerhead turtles are better elucidated by satellite telemetry than by nocturnal tagging efforts: implications for stock estimation. J Exp Mar Biol Ecol 383:48-55

> Van Dam RP, Diez CE, Balazs GH, Colón Colón LA, McMillan WO, Schroeder B (2008) Sex-specific migration patterns of hawksbill turtles breeding at Mona Island, Puerto Rico. Endang Species Res 4:85-94

Wallace BP, DiMatteo AD, Hurley BJ, Finkbeiner EM and others (2010) Regional management units for marine turtles: a novel framework for prioritizing conservation and

Editorial responsibility: Rory Wilson,

Swansea, UK research across multiple scales. PLoS One 5:e15465

- Wallace BP, DiMatteo AD, Bolten AB, Chaloupka MY and others (2011) Global conservation priorities for marine turtles. PLoS One 6:e24510

$>$ Whiting SD, Long JL, Coyne M (2007) Migration routes and foraging behaviour of olive ridley turtles Lepidochelys olivacea in northern Australia. Endang Species Res 3:1-9

- Wilcove DS, Wikelski M (2008) Going, going, gone: Is animal migration disappearing? PLoS Biol 6:e188

> Wilson RP, Shepard ELC, Liebsch N (2008) Prying into the intimate details of animal lives: use of a daily diary on animals. Endang Species Res 4:123-137

Witt MJ, Åkesson S, Broderick AC, Coyne MS and others (2010) Assessing accuracy and utility of satellite-tracking data using Argos-linked Fastloc-GPS. Anim Behav 80: 571-581

Witt MJ, Bonguna EA, Broderick AC, Coyne MS and others (2011) Tracking leatherback turtles from the world's largest rookery: assessing threats across the South Atlantic. Proc Biol Sci 278:2338-2347

Zbinden JA, Bearhop S, Bradshaw P, Gill B, Margaritoulis D, Newton J, Godley BJ (2011) Migratory dichotomy and associated phenotypic variation in marine turtles revealed by satellite tracking and stable isotope analysis. Mar Ecol Prog Ser 421:291-302

Submitted: July 11, 2011; Accepted: November 24, 2011

Proofs received from author(s): March 6, 2012 